\title{
Methylocella palustris gen. nov., sp. nov., a new methane-oxidizing acidophilic bacterium from peat bogs, representing a novel subtype of serine-pathway methanotrophs
}

\author{
Svetlana N. Dedysh, ${ }^{1,5}$ Werner Liesack, ${ }^{2}$ Valentina N. Khmelenina, ${ }^{3}$ \\ Natalia E. Suzina, ${ }^{3}$ Yuri A. Trotsenko, ${ }^{3}$ Jeremy D. Semrau, ${ }^{4}$ \\ Amy M. Bares, ${ }^{4}$ Nicolai S. Panikov ${ }^{1}$ and James M. Tiedje ${ }^{5}$
}

Author for correspondence: Svetlana N. Dedysh. Tel: +7 95135 0591. Fax: +7951356530. e-mail:dedysh@inmi.host.ru

\footnotetext{
1 Institute of Microbiology, Russian Academy of Sciences, Moscow 117811, Russia

2 Max-Planck-Institut für Terrestrische Mikrobiologie, D-35043 Marburg, Germany

3 Institute of Biochemistry and Physiology of Microorganisms, Russian Academy of Sciences, Pushchino, Moscow region 142292, Russia

4 Department of Civil and Environmental Engineering, The University of Michigan, Ann Arbor, MI 48109-2125, USA

5 Center for Microbial Ecology, Michigan State University, East Lansing، MI 48824-1325, USA
}

\begin{abstract}
A new genus, Methylocella, and a new species, Methylocella palustris, are proposed for three strains of methane-oxidizing bacteria isolated from acidic Sphagnum peat bogs. These bacteria are aerobic, Gram-negative, colourless, non-motile, straight and curved rods that utilize the serine pathway for carbon assimilation, multiply by normal cell division and contain intracellular poly- $\beta$ hydroxybutyrate granules (one at each pole). These strains use methane and methanol as sole sources of carbon and energy and are moderately acidophilic organisms with growth between pH 4.5 and pH 7.0, the optimum being at pH 5.0-5.5. The temperature range for growth is $10-28^{\circ} \mathrm{C}$ with the optimum at 15-20 ${ }^{\circ} \mathrm{C}$. The intracytoplasmic membrane system is different from those of type I and II methanotrophs. Cells contain an extensive periplasmic space and a vesicular membrane system connected to the cytoplasmic membrane. The strains grew only on media with a low salt content $\left(0.2-0.5 \mathrm{~g} \mathrm{I}^{-1}\right)$. All three strains were found to possess soluble methane monooxygenase and are able to fix atmospheric nitrogen via an oxygen-sensitive nitrogenase. No products were observed in a PCR with particulate methane monooxygenase-targeted primers; hybridization with a pmoA probe was also negative. The major phospholipid fatty acids are 18:1 acids. The G+C content of the DNA is $61.2 \mathrm{~mol} \%$. The three strains share identical 16S rRNA gene sequences and represent a novel lineage of methane-oxidizing bacteria within the $\alpha$-subclass of the class Proteobacteria and are only moderately related to type II methanotrophs of the Methylocystis-Methylosinus group. The three strains are most closely related to the acidophilic heterotrophic bacterium Beijerinckia indica subsp. indica (96.5\% 165 rDNA sequence similarity). Collectively, these strains comprise a new species and genus Methylocella palustris gen. nov., sp. nov.; strain $K^{\mathrm{T}}$ ( = ATCC 700799') is the type strain.
\end{abstract}

Keywords: Methylocella palustris gen. nov., sp. nov., acidophilic methane-oxidizing bacteria, serine-pathway methanotrophs

\section{INTRODUCTION}

Methane-oxidizing bacteria (MOB) are a ubiquitous group of micro-organisms possessing the unique ability to utilize methane as the sole source of carbon

Abbreviations: FAME, fatty acid methyl ester; ICM, intracytoplasmic membrane; $\mathrm{MOB}$, methane-oxidizing bacteria; $\mathrm{PMMO}$, particulate methane monooxygenase; sMMO, soluble methane monooxygenase.

The EMBL/GenBank/DDBJ accession number for the 16S rRNA gene of Methylocella palustris strain $\mathrm{K}^{\top}$ is $\mathrm{Y} 17144$. and energy. The current classification separates all the known methanotrophs into three groups (types I, II and $\mathrm{X}$ ) by multiple criteria, including cell morphology, the arrangement of intracytoplasmic membranes, the pathway for formaldehyde assimilation, the DNA $\mathrm{G}+\mathrm{C}$ content and the major phospholipid fatty acids. Both 5S rRNA and 16S rRNA sequence analyses indicated that all known MOB form phylogenetically coherent clusters within the $\alpha$ - and $\gamma$-subclasses of the Proteobacteria (Hanson \& Hanson, 1996).

Although MOB have been isolated from diverse 
environments including soils, sediments, wetlands, freshwater and marine habitats (Whittenbury et al., 1970a; Hanson \& Hanson, 1996; King, 1992), the known ecophysiological types of methanotrophs are quite limited. Most MOB available in pure cultures are both mesophilic and neutrophilic; however, thermophilic (Bodrossy et al., 1997), psychrophilic (Omelchenko et al., 1993; Bowman et al., 1997) and alkaliphilic (Khmelenina et al., 1997) methanotrophs have been described.

Until recently, MOB that colonize acidic environments remained unknown and pure cultures of acidophilic methanotrophs were absent from culture collections. Last year, however, we reported on the enrichment of methanotrophic communities from acidic peat bogs of four boreal sites in West Siberia and European North Russia (Dedysh et al., 1998a) and on the isolation of three pure cultures of MOB from these enrichments (Dedysh et al., 1998b). These isolates are the first representatives of a new group of previously unculturable MOB and initial studies have revealed them to be considerably different from other methanotrophs. The 16S rRNA gene sequence data indicate that the acidophilic strains represent a novel lineage of MOB only moderately related to the known cluster of $\alpha$ proteobacterial methanotrophs, i.e. MethylosinusMethylocystis spp. (Dedysh et al., 1998b). Furthermore, the acidophilic strains are most closely affiliated with the heterotrophic bacterium Beijerinckia indica subsp. indica, while no other known group of methanotrophs has any close relatives that are not methanotrophs (Hanson \& Hanson, 1996). The nucleotide sequence of the PCR-amplified fragment of the mmoX gene [which encodes the $\alpha$-subunit of the soluble methane monooxygenase (sMMO) hydroxylase] in these acidophilic methanotrophs diverges significantly from these gene fragments in known methanotrophs and forms a branch that is distinct from the two known mmoX sequence groups [the MethylocystisMethylosinus-like mmoX sequences and the Methylococcus capsulatus (Bath) $m m o X$ sequence].

In this paper we describe the cell ultrastructure and physiology of these three methanotrophic isolates from peat bogs, as well as their biochemical, chemotaxonomic and genotypic characteristics. We propose a new genus, Methylocella gen. nov., and the species Methylocella palustris sp. nov. for these strains.

\section{METHODS}

Bacterial strains and culture conditions. Strains $\mathrm{K}^{\mathrm{T}}$, S6 and M131 were isolated from methanotrophic enrichments of three different Sphagnum peat bogs (Dedysh et al., 1998a). The isolation procedure and the culture conditions used were described elsewhere (Dedysh et al., 1998b). The fivefold dilution of minimal mineral medium M1 (Dedysh et al., 1998a), designated as medium M2 was used for strain cultivation. Solid M2 medium was prepared by adding $1.5 \%$ $(\mathrm{w} / \mathrm{v})$ purified agar (Difco). After sterilization, the medium was adjusted to $\mathrm{pH} 5 \cdot 0-5 \cdot 5$ with $0 \cdot 1 \mathrm{M} \mathrm{H}_{3} \mathrm{PO}_{4}$. The isolates were maintained both on M2-agar medium slants and in liquid cultures. In the latter case, M2 medium was supplemented with $0.5 \%(\mathrm{v} / \mathrm{v})$ of a vitamin stock solution containing the following (mg per $100 \mathrm{ml})$ : biotin (0.4); nicotinic acid (10); riboflavin (10); and inositol (10). To study the ultrastructure of cells grown in $\mathrm{Cu}$-rich medium, copper was added aseptically as $\mathrm{CuCl}_{2} \cdot 2 \mathrm{H}_{2} \mathrm{O}$ to $\mathrm{M} 2$ medium after autoclaving to achieve a copper concentration of $5 \mu \mathrm{M}$. For growth, screw-cap $500 \mathrm{ml}$ serum bottles were used with a headspace: liquid-space ratio of $4: 1$. After inoculation, the bottles were sealed with silicone rubber septa and methane was added aseptically by a syringe equipped with a disposable filter $(0 \cdot 22 \mu \mathrm{m})$ to achieve a $15-20 \%$ concentration in the headspace. Bottles were incubated on a rotary shaker (200 r.p.m.) at $20^{\circ} \mathrm{C}$. Methanotrophic bacteria were subcultured at 4-5-week intervals.

Reference bacterial strains. Methylococcus capsulatus (Bath) ATCC $33009^{\mathrm{T}}$, Methylosinus sporium NCIMB $11126^{\mathrm{T}}$, Methylosinus trichosporium OB3b NCIMB $11131^{\mathrm{T}}$, Methylocystis parvus OBBP NCIMB $11129^{\mathrm{T}}$, Methylomicrobium album BG8 ATCC 33003, Beijerinckia indica subsp. indica ATCC $9039^{\mathrm{T}}$ and Rhodopseudomonas acidophila ATCC $25092^{\mathrm{T}}$ were used as reference strains. The methanotrophs were cultivated on NMS medium with methane as the growth substrate (Whittenbury et al., 1970a), while Beijerinckia indica was grown on nitrogen-free mineral medium with glucose (Becking, 1984) and Rhodopseudomonas acidophila was grown in the light under anaerobic conditions on succinate/mineral medium (Pfennig, 1969).

Verification of strain purity. Both phase-contrast and electron microscopy were used to check the acidophilic isolates for contamination. The absence of heterotrophic satellites was checked by plating methanotrophic isolates on several media containing different organic substrates. These media were as follows: standard undiluted and 10-fold-diluted Luria-Bertani agar (1.0\% tryptone, $0.5 \%$ yeast extract, $1.0 \% \mathrm{NaCl}$ ) and $\mathrm{M} 2$-agar media (Noble agar) amended with $0.1 \%(\mathrm{w} / \mathrm{v})$ glucose, fructose or sucrose. As a control, the same agar mineral medium was used without any organic substrates. To prove the homogeneity of isolated methanotrophic strains, the cells were grown on methane and methanol with subsequent RFLP analysis of the cloned 16S rRNA genes to examine possible shifts in population structure. For RFLP analysis, a single colony of every strain was used to inoculate a liquid culture. This culture was grown on methane to the mid-exponential phase. Then cells were collected by centrifugation and divided into two parts, one of which was again grown in liquid culture with methane, while the other sample was transferred to M2 medium containing $0.3 \%(\mathrm{w} / \mathrm{v})$ methanol. After $5 \mathrm{~d}$ incubation, the cells were harvested, genomic DNA was extracted from both cultures by using an SDS-based method (see Methods). PCR-mediated amplification of $16 \mathrm{~S}$ rRNA genes was performed with an oligonucleotide primer set useful for most members of the domain Bacteria (Weisburg et al., 1991). The PCR-amplified 16S rRNA gene products were quantified and ligated into the pCR II vector provided with the TA cloning kit (Invitrogen). Screening of recombinant clones was performed by direct amplification of the cloned inserts using vector-specific primers (Zhou et al., 1997). The constructed 16S rDNA clone library was then reamplified and restriction digested by two sets of tetrameric endonucleases, i.e. MspI + RsaI and HhaI + HaeIII (Gibco-BRL Life Technologies). The resulting restriction products were separated by gel electrophoresis in 3.5\% (w/v) Metaphor agarose (FMS Bioproducts) stained with $0.5 \mu \mathrm{g}$ ethidium bromide $\mathrm{ml}^{-1}$ in $1 \times$ Tris borate/EDTA at $4{ }^{\circ} \mathrm{C}$ for $5 \mathrm{~h}$. 
Morphological observations. Cell size measurement and shape classification were performed by using the imageanalysis system developed at the Center for Microbial Ecology at Michigan State University (Liu et al., 1998). The Gram-stain reaction and lysis in $3 \%(\mathrm{w} / \mathrm{v}) \mathrm{KOH}$ (Gerhardt, 1981) were carried out with both 2 - and 4-week-old cultures. Capsules were stained with $2.5 \%(\mathrm{w} / \mathrm{v})$ nigrosine and observed using oil-immersion phase-contrast microscopy. Poly- $\beta$-hydroxybutyrate inclusions were determined by staining with $0.03 \%(\mathrm{w} / \mathrm{v})$ Sudan black and 0.5\% safranin (Gerhardt, 1981). The observations of rosette formation, as well as checks for the presence of exospores or cysts, were carried out during all phases of growth on both liquid and agar media. Exospore formation was also assayed by determining cell viability after heating a 2-week-old cell suspension at $80{ }^{\circ} \mathrm{C}$ for $20 \mathrm{~min}$ and then observing microcolony formation on M2 agar medium after 5 and $10 \mathrm{~d}$ incubation with methane. The same procedure was used to determine the proportion of viable cells after measuring cell resistance to desiccation (Whittenbury et al., 1970b). Lysis by 0.2 and $2 \%(\mathrm{w} / \mathrm{v})$ SDS was determined spectrophotometrically $\left(\mathrm{OD}_{410}\right)$ and by direct microscopic observation. Colony morphology and pigmentation were examined with 2, 4 and 6-week-old M2-agar-plate cultures.

Electron microscopy. Thin sections were examined using batch cultures grown to the early exponential, lateexponential and stationary growth phases. Cells were collected by centrifugation and pre-fixed with $1.5 \%(\mathrm{w} / \mathrm{v})$ glutaraldehyde in $0.05 \mathrm{M}$ cacodylate buffer $(\mathrm{pH} 6.5)$ for $1 \mathrm{~h}$ at $4{ }^{\circ} \mathrm{C}$ and then fixed in $1 \%(\mathrm{w} / \mathrm{v}) \mathrm{OsO}_{4}$ in the same buffer for $4 \mathrm{~h}$ at $20^{\circ} \mathrm{C}$. After dehydration in an ethanol series, the samples were embedded in a Spurr epoxy resin. Thin sections were cut on an LKB-4800 microtome, stained with $3 \%$ $(\mathrm{w} / \mathrm{v})$ uranyl acetate in $70 \%(\mathrm{v} / \mathrm{v})$ ethanol and then poststained with lead citrate (Reynolds, 1963). The specimen samples were examined with a JEOL JEM 100B transmission electron microscope at an accelerating voltage of $80 \mathrm{kV}$.

Cell morphology was examined using batch cultures in the late-exponential growth phase. The procedure used for sample fixation and preparation was as described previously (Dedysh et al., 1998a). Cells were examined with a JEOL JSM-6400V scanning electron microscope.

Physiological tests. Growth at various temperatures ranging from 4 to $45^{\circ} \mathrm{C}$ as well as tolerance to $\mathrm{NaCl}$ at concentrations ranging from 0.01 to $1 \%(\mathrm{w} / \mathrm{v})$ was determined with M2 agar cultures. Tolerance to dyes $[0.001 \%(\mathrm{w} / \mathrm{v})$ malachite green, $0.01 \%$ methylene blue and $0.001 \%$ crystal violet] was tested by incorporating dyes into M2 agar plates. Sensitivity to antibiotics was examined by spreading cells on to an M2 agar medium and applying filter discs containing the following antibiotics: erythromycin $\left(15 \mu \mathrm{g} \mathrm{ml}^{-1}\right)$, linkomycin $\left(2 \mu \mathrm{g} \mathrm{ml}^{-1}\right)$, gentamicin $\left(10 \mu \mathrm{g} \mathrm{ml}^{-1}\right)$, novobiocin $(5 \mu \mathrm{g}$ $\left.\mathrm{ml}^{-1}\right)$, nalidixic acid $\left(30 \mu \mathrm{g} \mathrm{ml}^{-1}\right)$ and streptomycin $(10 \mu \mathrm{g}$ $\mathrm{ml}^{-1}$ ). Growth under methane was assessed after 2 weeks. The ability to grow under microaerobic conditions was determined in growth experiments with $5 \% \mathrm{O}_{2}$ concentration in the headspace of incubation flasks. Nitrogen fixation was assayed on nitrogen-free M2 medium with batch cultures in the mid-exponential growth phase by using the acetylene-reduction procedure of Takeda (1988). Prior to acetylene injection, the incubation flasks were divided into two groups: one group of flasks was flushed with sterile air to remove any remaining methane, whereas the other flasks were purged with sterile dinitrogen to remove methane and oxygen, with oxygen subsequently being added by syringe to a $5 \%(\mathrm{v} / \mathrm{v})$ concentration in the headspace.
Methanol was added to the flasks at a concentration of $0.01 \%(\mathrm{v} / \mathrm{v})$. The amount of ethylene produced was measured after $15 \mathrm{~h}$ incubation on a rotary shaker (200 r.p.m.) at $20^{\circ} \mathrm{C}$.

Range of utilizable carbon and nitrogen sources. The following carbon sources (each at a concentration of $0 \cdot 1 \%$, $\mathrm{w} / \mathrm{v}$ ) were examined to determine the range of substrates that can be utilized for growth and energy by the acidophilic methanotrophic isolates: formate, formamide, urea, methylamine, dimethylamine, trimethylamine, tetramethylammonium chloride, glucose, fructose, sucrose, arabinose, lactose, xylose, maltose, raffinose, ribose, galactose, acetate, citrate, oxalate, mannitol and sorbitol. The capacity to utilize methanol at concentrations ranging from 0.01 to $0.5 \%(\mathrm{v} / \mathrm{v})$ was determined by measuring the growth dynamics $\left(\mathrm{OD}_{410}\right.$ and $\mathrm{CO}_{2}$ production) of all three strains on M2 liquid medium with methanol. Nitrogen sources were also tested using M2 agar medium in which $\mathrm{KNO}_{3}$ was replaced with one of the following compounds at a concentration of $0.05 \%(\mathrm{w} / \mathrm{v}): \mathrm{NaNO}_{2},\left(\mathrm{NH}_{4}\right)_{2} \mathrm{SO}_{4}$, glycine, DLalanine, L-serine, L-threonine, L-valine, L-leucine, L-isoleucine, L-proline, L-cysteine, L-methionine, L-glutamate, Laspartate, L-glutamine, L-asparagine, L-histidine, L-phenylalanine, L-tryptophan, L-arginine, L-lysine, L-ornithine, Lcitrulline or yeast extract. Growth was examined after $30 \mathrm{~d}$ incubation and confirmed by comparison with the negative control (grown on nitrogen-free M2 agar medium).

Analytical techniques. $\mathrm{CH}_{4}$ and $\mathrm{C}_{2} \mathrm{H}_{4}$ were measured with a gas chromatograph equipped with a flame-ionization detector. $\mathrm{CO}_{2}$ and $\mathrm{O}_{2}$ were analysed by $\mathrm{GC}$ with a thermoconductivity detector. All measurements were performed using triplicate samples. Cell biomass was measured by converting optical density at $410 \mathrm{~nm}$ to cell carbon, using the appropriate calibration curve.

Genomic bacterial DNA isolation. Chromosomal DNA from methanotrophic isolates and reference bacterial strains was extracted using the SDS-based assay as described previously (Dedysh et al., 1998a).

Comparative sequence analysis of the 16S rRNA gene. The 16S rRNA gene sequences from Methylosinus sporium (NCIMB $11126^{\mathrm{T}}$ ), Methylosinus trichosporium OB3b (NCIMB $11131^{\mathrm{T}}$ ) and Methylocystis parvus OBBP (NCIMB $11129^{\mathrm{T}}$ ) were determined for reference purposes. PCRmediated amplification of the $16 \mathrm{~S}$ rRNA genes from positions 28-1491 (using numbering according to the International Union of Biochemistry nomenclature for Escherichia coli $16 \mathrm{~S}$ rRNA) and sequencing were carried out as already described for the acidophilic strains $\mathrm{K}^{\mathrm{T}}, \mathrm{M} 131$ and S6 (Dedysh et al., 1998b). The phylogenetic position of the three acidophilic methanotrophs was determined by comparing their 16S rRNA gene sequences with $\alpha$-proteobacterial reference sequences for which at least 1400 determined nucleotide sequence positions were available. Distance matrix [ARB (Strunk et al., 1996) and PHYLIP (Felsenstein, 1993)], maximum-likelihood [ARB and fastDNAml (Maidak et al., 1997)] and maximum-parsimony methods [ARB and PHYLIP (Felsenstein, 1993)] were used for tree reconstruction. Several trees were generated for each of these treeing methods: these trees differed in terms of (i) the $\alpha$-proteobacterial reference sequences used and (ii) the set of alignment positions used for tree reconstruction. These sets were determined for a sequence stretch at $E$. coli positions 28-1477 and were based on a $50 \%$ invariance criterion (Friedrich et al., 1996) by using the complete data set consisting of 424 reference sequences or by using subsets of 
these sequences and the appropriate tool of the ARB program package. The statistical significance of interior branch points was tested in bootstrap analyses by using neighbour-joining methods (ARB; 1000 data resamplings).

PCR amplification of the pmoA gene and hybridization experiments. Two sets of primers were used to amplify specific fragments of the pmo $A$ gene encoding the $27 \mathrm{kDa}$ polypeptide of particulate methane monooxygenase (pMMO) from the chromosomal DNA of Methylococcus capsulatus (Bath), Methylosinus trichosporium OB3b, Methylomicrobium album BG8 and all three acidophilic isolates, strains $\mathrm{K}^{\mathrm{T}}, \mathrm{S} 6$ and M131. Primers A189 (5'GGNGACTGGGACTTCTGG-3') and A682 (5'-GAASGCNGAGAAGAASGC-3') were used to amplify a 525 bp portion of pmoA (Holmes et al., 1995) and primers A189 and mb661 (5'-CCGGMGCAACGTCYTTACC-3') were used to amplify a $510 \mathrm{bp}$ fragment of pmo A (Costello \& Lidstrom, 1999). Amplification was carried out on an Eppendorf Mastercycler using the reaction conditions described by MacDonald et al. (1995).

Genomic DNA was collected from Methylococcus capsulatus (Bath), Methylosinus trichosporium OB3b, Methylomicrobium album $\mathrm{BG} 8$ and strain $\mathrm{K}^{\mathrm{T}}$, using the SDS procedure described earlier (Dedysh et al., 1998a). The chromosomal DNA was digested with restriction enzymes SalI, PstI, BamHI, EcoRI and HindIII as recommended by the supplier (Boehringer Mannheim). The digested DNA was separated by using standard procedures on $1 \%(\mathrm{w} / \mathrm{v})$ agarose Tris borate gels and then transferred to nylon membranes (Roche Molecular Biolabs) as outlined by Sambrook et al. (1989). Hybridizations were performed using the $510 \mathrm{bp}$ PCR product of the pmo $A$ gene of Methylococcus capsulatus (Bath), with primers A189 and mb661. This PCR product was labelled using digoxigenindUTP according to the instructions of the manufacturer (Boehringer Mannheim) and hybridization was performed overnight at $42^{\circ} \mathrm{C}$. The membranes were then washed twice in $2 \times$ SSC (Sambrook et al., 1989)/0.1\% SDS at 60 and $62{ }^{\circ} \mathrm{C}$ for $15 \mathrm{~min}$ and then exposed to X-ray film.

Whole-cell fatty acid analysis. Methanotrophic isolates were grown on M2 mineral medium with methane (Dedysh et al., 1998a) and Beijerinckia indica was grown on mineral medium with glucose (Becking, 1984). Cells were collected in the late-exponential growth phase. Saponification, methylation and extraction of fatty acids were performed by using the procedure described by Sasser (1990). Analysis of the fatty acid methyl esters (FAMEs) was carried out using an HP 5890 series II gas chromatograph (Hewlett Packard) equipped with a flame-ionization detector and a 7673 automatic sampler. Samples were separated on an HP ultra2 (cross-linked 5\% phenyl methyl silicone) column $25 \mathrm{~m} \times 0.2 \mathrm{~mm}$ diameter with a film thickness of $0.33 \mu \mathrm{m}$. The carrier gas was ultrahigh purity hydrogen at $50 \mathrm{ml} \mathrm{min} \mathrm{m}^{-1}$ with a split ratio of $50: 1$. An initial temperature of $170{ }^{\circ} \mathrm{C}$ was ramped to $270{ }^{\circ} \mathrm{C}$ at a rate of $5^{\circ} \mathrm{C} \min ^{-1}$. The column was baked after each run for $2 \mathrm{~min}$ at $300^{\circ} \mathrm{C}$. Injector and detector temperatures were held at 250 and $300^{\circ} \mathrm{C}$, respectively. Fatty acid profiles were quantified and identified using the Sherlock Microbial Identification system (MIDI).

Enzyme assays. For enzymic studies, the cultures were harvested in the late exponential or early stationary growth phase. Cells were sedimented by centrifugation (4000 g, 30 min), washed with $0.05 \mathrm{M} \mathrm{K} / \mathrm{Na}$-phosphate ( $\mathrm{pH} 6.8$ ) or Tris $/ \mathrm{HCl}(\mathrm{pH} \mathrm{7.2)}$ buffer, resuspended in the same buffer and disrupted in cooled $10 \mathrm{ml}$ cuvettes using an MSE ultrasonic disintegrator $(150 \mathrm{~W}, 20 \mathrm{kHz}, 4 \times 30 \mathrm{~s})$. Cell debris was removed by centrifugation at $6000 \mathrm{~g}$ for $30 \mathrm{~min}$. The resulting supernatant was centrifuged again at $30000 \boldsymbol{g}$ for $1 \mathrm{~h}$ for separation of the membrane fraction.

The activities of methanol dehydrogenase (EC 1.1.88.8), phenazine methosulfate-, NAD- and glutathione-dependent formaldehyde dehydrogenases (EC 1.2.1.1), formate dehydrogenase (EC 1.2.1.2), NADH-dehydrogenase, hexulosephosphate synthase, pyrophosphate-dependent 6-phosphofructokinase (EC 2.7.1.90), ATP-dependent 6-phosphofructokinase (EC 2.7.1.11), fructose-1,6bisphosphate aldolase (EC 4.1.2.13), 6-phosphogluconate dehydratase/2-keto-3-deoxy-6-phosphogluconate aldolase (EC 4.1.2.14), hydroxypyruvate reductase (EC 1.1.1.29), serine-glyoxylate aminotransferase (EC 2.6.1.45), ribulose-1,5-bisphosphate carboxylase/oxygenase (EC 4.1.1.39), phosphoribulokinase (EC 2.7.1.19) isocitrate lyase (EC 1.2.4.1), malate synthase, (EC 4.1.3.2), malate dehydrogenase (EC 1.1.1.37), isocitrate dehydrogenase (EC 1.1.1.42), pyruvate dehydrogenase (EC 1.2.4.1), $\alpha$-ketoglutarate dehydrogenase (EC 1.2.4.2), glutamate dehydrogenase (EC 1.4.1.2), alanine dehydrogenase (EC 1.4.1.1), glutamate synthase (EC 2.6.1.53) and glutamine synthetase (EC 6.3.1.2) were assayed as described previously (Shishkina \& Trotsenko, 1979, 1982). The sMMO activity was measured by using a colorimetric assay with tetrazotized $o$-dianisidine (Phelps et al., 1992).

DNA base composition analysis. The DNA base composition was determined by using the thermal denaturation method with an SP1800 spectrophotometer (Unicam) at a heating rate of $0.5{ }^{\circ} \mathrm{C} \mathrm{min}^{-1}$. The $\mathrm{G}+\mathrm{C}$ content of the DNA (mol \%) was calculated using the equation of Owen et al. (1969): $\mathrm{mol} \% \mathrm{G}+\mathrm{C}=\left(T_{\mathrm{m}} \times 2 \cdot 08\right)-106 \cdot 4$. The DNA of E. coli $\mathrm{K}-12$ was used as the standard.

Nucleotide sequence accession numbers. The nucleotide sequence of the 16S rRNA gene of Methylocella palustris strain $\mathrm{K}^{\mathrm{T}}$ has already been deposited in the EMBL, GenBank and DDBJ nucleotide sequence databases under accession number Y17144 (Dedysh et al., 1998b). The nucleotide sequences of the 16S rRNA genes of Methylocystis parvus NCIMB $11129^{\mathrm{T}}$, Methylosinus sporium NCIMB $11126^{\mathrm{T}}$ and Methylosinus trichosporium NCIMB $11131^{\mathrm{T}}$, determined for reference purposes, have EMBL/GenBank/DDBJ nucleotide sequence databases accession numbers Y18945, Y 18946 and Y18947, respectively. The accession numbers of the 16S rRNA gene sequences used as references for the reconstruction of the tree are as follows: Ancylobacter aquaticus ATCC 25396 ${ }^{\mathrm{T}}$, M62790; Azorhizobium caulinodans ATCC 43989 ${ }^{\mathrm{T}}$, X67221; Azospirillum lipoferum ATCC $29707^{\mathrm{T}}$, M59061; Beijerinckia indica ATCC 9039 ${ }^{\mathrm{T}}$, M59060; Blastochloris viridis ATCC 19567 ${ }^{\mathrm{T}}$, D25314; Brucella suis ATCC 23444 ${ }^{\mathrm{T}}$, L26169; Methylobacterium organophilum ATCC 27886 ${ }^{\mathrm{T}}$, D32226; Rhodoplanes elegans ATCC 51906 ${ }^{\mathrm{T}}$, D25311; Rhodopseudomonas acidophila ATCC 25092 ${ }^{\mathrm{T}}$, M34128; Rhodopseudomonas palustris ATCC $17001^{\mathrm{T}}$, D25312.

\section{RESULTS \\ Colony morphology}

Visible, but very small (about $0 \cdot 1-0.3 \mathrm{~mm}$ ), colonies were observed on M2 agar after at least 2 weeks incubation. After growth on plates for 6 weeks, the colonies were highly raised, had a tough slime con- 

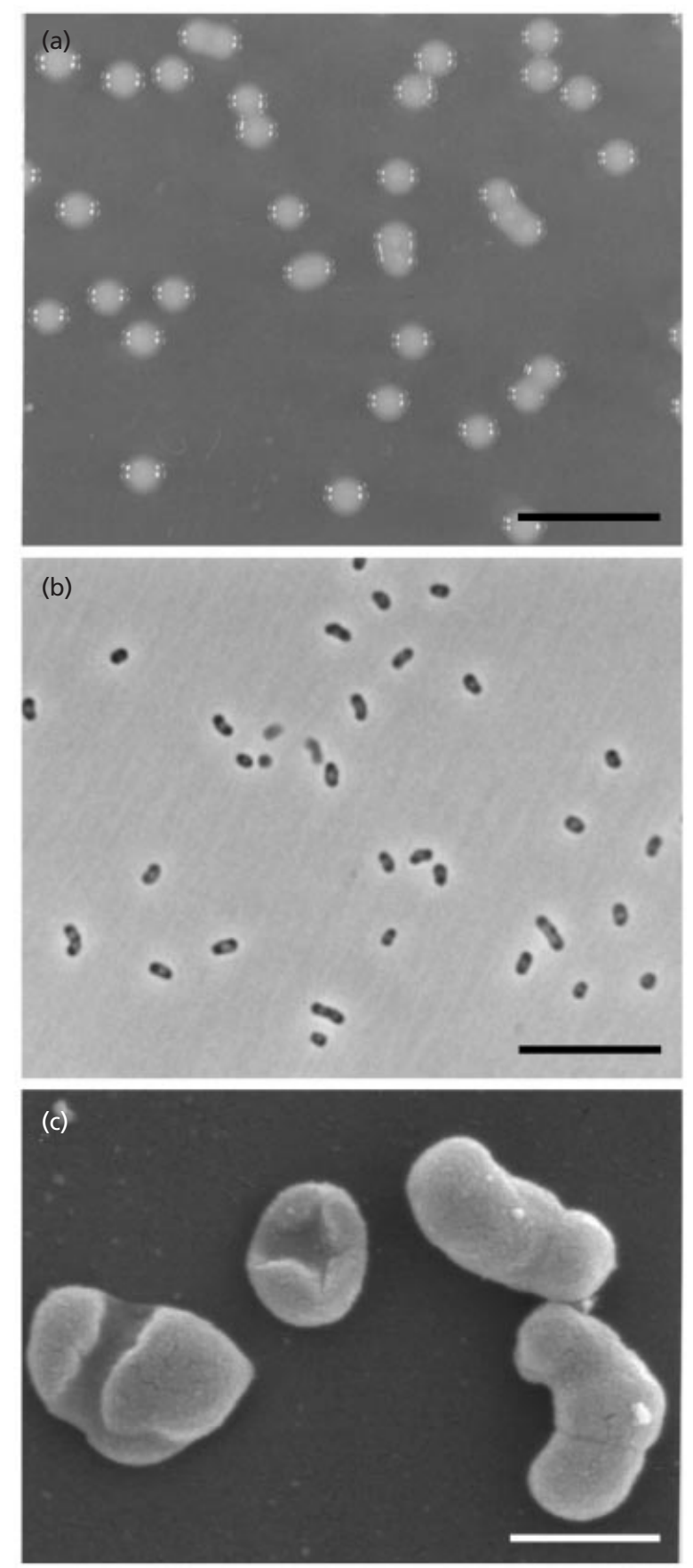

Fig. 1. (a) Six-week-old colonies of strain $K^{\top}$ on $M 2$ agar medium; bar, $0.5 \mathrm{~cm}$. (b) Phase-contrast micrograph of strain $\mathrm{K}^{\top}$ grown on methane for $10 \mathrm{~d}$, showing the typical bipolar appearance of the cells; bar, $10 \mu \mathrm{m}$. (c) Scanning electron micrograph of cells of strain S6.

sistency, were circular with an entire margin and a smooth surface and were $1-2 \mathrm{~mm}$ in diameter (Fig. 1a). Colonies $2-3$ months old occasionally had a folded or slightly plicated surface. Initially, the colonies were semi-transparent or uniformly turbid, but became opaque white over time.

\section{Cell morphology and ultrastructure}

The cells of strains $\mathrm{K}^{\mathrm{T}}$, S6 and M131 were Gramnegative, non-motile, polymorphic, straight or curved rods with rounded ends occurring singly or in shapeless aggregates, but did not form rosettes during any growth stage (Fig. 1c). The cells were $0 \cdot 6-1 \cdot 0 \mu \mathrm{m}$ wide by $1.0-2.5 \mu \mathrm{m}$ long and reproduced by normal cell division. The major distinctive feature of the cells was their highly specific bipolar appearance, which was easily observable even under phase-contrast microscopy (Fig. 1b). This was due to large, highly refractile, intracellular granules of poly- $\beta$-hydroxybutyrate formed at each cell pole (Fig. 2a). When grown on agar media, cells produced capsules approximately $0 \cdot 2-1$ $\mu \mathrm{m}$ thick. Exospores resembling those of Methylosinus were observed in very low numbers in cultures more than 4 months old (Fig. 2d). The examination of a younger cultures did not reveal exospores and these cultures were not heat resistant. Although no cysts or cyst-like cells were observed regardless of cell age and culture conditions, the cells were found to be resistant to desiccation. After 7 and $30 \mathrm{~d}$ desiccation, 13 and $9 \%$ of the cells, respectively, were able to form microcolonies. The cells were not lysed by $2 \%$ SDS.

The ultrastructure of all three strains was examined throughout the various stages of growth. Interestingly, regardless of the growth phase, the intracytoplasmic membrane (ICM) structures of acidophilic isolates were different from those seen in type I and type II MOB (Fig. 2). When grown under normal oxygen tension, the cells possessed an extensive periplasmic space containing a heterogeneous matrix of lower electron density relative to that of cytoplasm (Fig. 2a, b). The periplasmic space on cross-sections was $20-80 \mathrm{~nm}$ in width. Also, small spherical vesicles (60 $100 \mathrm{~nm}$ in diameter) bounded by three layered membranes were located on the periphery of the cytoplasm (Fig. 2c). The micrographs showed that these vesicles were formed by cytoplasmic membrane invaginations. The vesicular matrix had the same density as periplasmic matrix. In many cells of these isolates, however, the ICM system was either poorly developed or unobservable. The effect of different culture conditions on the cell ultrastucture was also examined in this study. Regardless of whether growth was oxygenlimited $\left(5 \% \mathrm{O}_{2}\right.$ in the headspace), the medium was supplemented with $5 \mu \mathrm{M}$ copper, or methanol was provided as a carbon and energy source $(0.03 \%, \mathrm{v} / \mathrm{v})$, neither type I nor type II ICM structures were formed. When the strains were grown under oxygen-limiting conditions, approximately one-third of the cells were observed to have large inclusions with periodic macromolecular structure (Fig. 2e, f).

\section{Purity criteria}

Examinations using both phase-contrast- and electron microscopy failed to reveal any contamination of the methanotrophic isolates by other bacteria, as judged from cell morphology. No growth was observed on 

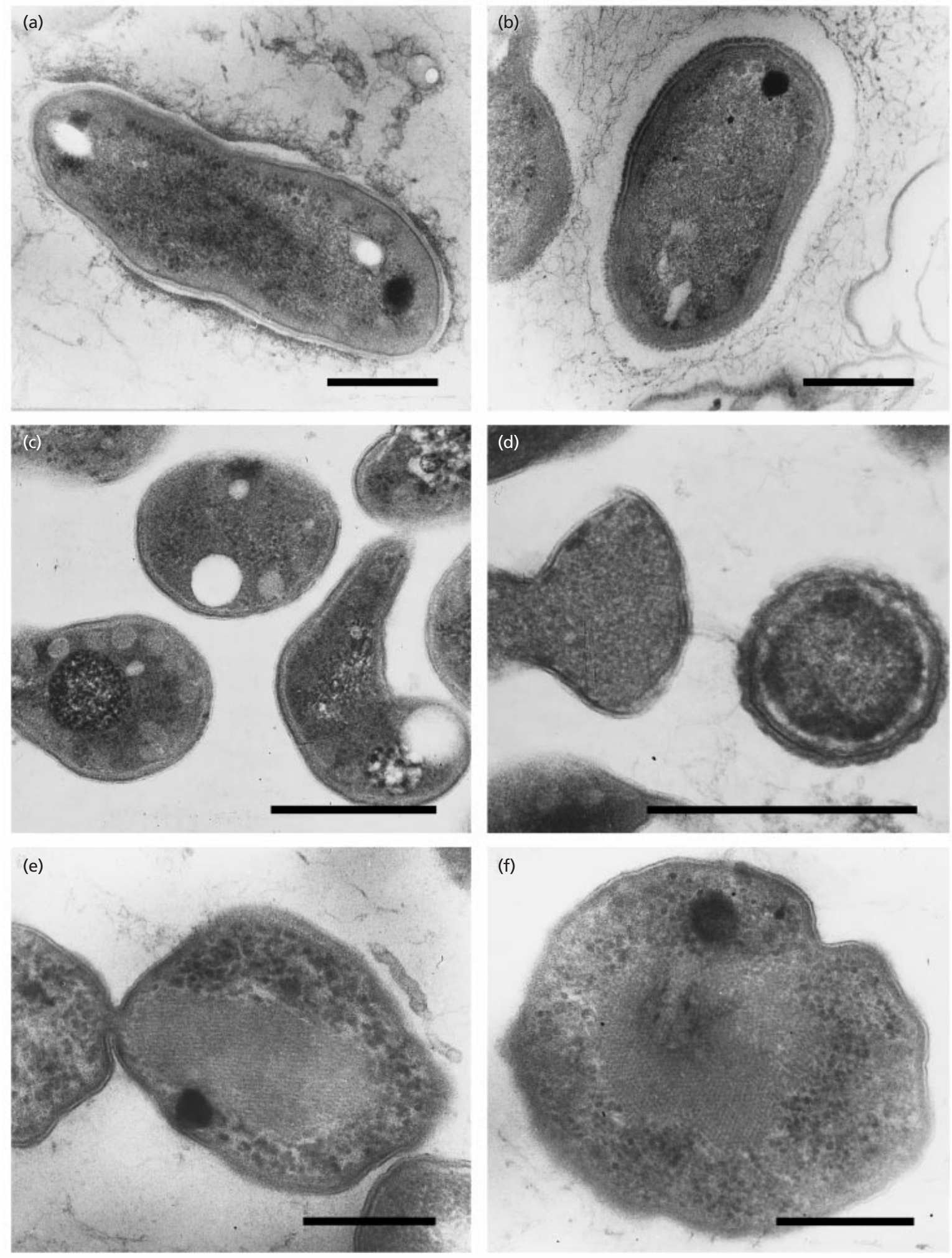

Fig. 2. For legend see facing page.

any of the complex organic media tested, whether diluted or undiluted. All three strains, when tested on agar mineral media with individual sugars, exhibited weak growth of the same low magnitude as that observed on control plates lacking any organic substrates. To further verify the purity, RFLPs between 
Table 1. Cellular fatty acid compositions of the three acidophilic methanotrophic isolates, Beijerinckia indica subsp. indica and type II methylotrophic bacteria

The numbers of carbon atoms and unsaturated carbon bonds, respectively, are given here in the form 12:0 (for example). ND, Not detected; N, no data.

\begin{tabular}{|c|c|c|c|c|c|c|c|}
\hline \multirow[t]{2}{*}{ Strain } & \multicolumn{7}{|c|}{ Percentage of total fatty acids } \\
\hline & $12: 0$ & $13: 0$ & $16: 1^{*}$ & $16: 0$ & $17: 0$ & $18: 1 \dagger$ & $18: 0$ \\
\hline Methylocella palustris $\mathrm{K}^{\mathrm{T}}$ & ND & ND & $18 \cdot 20$ & $8 \cdot 80$ & ND & $71 \cdot 20$ & $1 \cdot 80$ \\
\hline Methylocella palustris $\mathrm{S} 6$ & ND & ND & $18 \cdot 59$ & $8 \cdot 62$ & ND & $71 \cdot 47$ & $1 \cdot 33$ \\
\hline $\begin{array}{l}\text { Methylocella palustris } \\
\text { M131 }\end{array}$ & ND & ND & $13 \cdot 66$ & $7 \cdot 47$ & ND & $75 \cdot 94$ & $2 \cdot 93$ \\
\hline $\begin{array}{l}\text { Beijerinckia indica subsp. } \\
\text { indica }\end{array}$ & $1 \cdot 53$ & $0 \cdot 65$ & $1 \cdot 23$ & $4 \cdot 69$ & $1 \cdot 41$ & $89 \cdot 02$ & $1 \cdot 47$ \\
\hline $\begin{array}{l}\text { Methylosinus and } \\
\text { Methylocystis spp.\$ }\end{array}$ & $\mathrm{N}$ & $\mathrm{N}$ & $0 \cdot 3-15$ & $0-1 \cdot 5$ & ND & $75-87$ & $0 \cdot 4-5$ \\
\hline Methylobacterium spp. $\$$ & $\mathrm{~N}$ & $\mathrm{~N}$ & $0-6 \cdot 4$ & $3-6 \cdot 4$ & $0 \cdot 2-0 \cdot 4$ & $81-85$ & $6 \cdot 9-8 \cdot 6$ \\
\hline
\end{tabular}

* Mixture of $\omega 7 c / \omega 7 t$.

$\dagger$ Mixture of $\omega 7 c / \omega 7 t / \omega 8 c / \omega 8 t / \omega 9 c$.

$\$$ Data are from Bowman et al. (1991) and Guckert et al. (1991).

individual 16S rRNA gene clones obtained from two batches of strain $\mathrm{K}^{\mathrm{T}}$ grown on different substrates were examined. In total, 86 16S rDNA clones (46 clones were retrieved from the culture incubated with methane and 40 clones were from the culture grown on methanol) were obtained and the restriction patterns compared. No differences were observed between any of the clones investigated using two different sets of tetrameric endonucleases. From these results, it can be concluded that strain $\mathrm{K}^{\mathrm{T}}$ is a homogeneous $16 \mathrm{~S}$ rDNAdefined population and, thus, represents a pure culture.

\section{Physiological characteristics}

The strains $\mathrm{K}^{\mathrm{T}}$, S6 and M131 were capable of growth on methane and methanol as the sole carbon and energy sources. Methanol supported growth only when used in low concentrations $(0 \cdot 01-0 \cdot 1 \%, \mathrm{v} / \mathrm{v})$, while it inhibited growth at concentrations above $0.3 \%(\mathrm{v} / \mathrm{v})$. Growth did not occur either on other $\mathrm{C}_{1}$ substrates or on the range of multicarbon compounds tested. The growth factors were not strictly required, but growth was stimulated by the addition of vitamins (biotin, nicotinic acid, riboflavin and inositol). All three strains utilized ammonium salts, nitrates and yeast extract as nitrogen sources; they were also able to fix atmospheric nitrogen when grown in nitrogen-free media. The acetylene-reduction activity of strains in microaerobic conditions was found to range from 5.0 to $8.2 \mathrm{nmol}$
$\mathrm{C}_{2} \mathrm{H}_{4} /(\mathrm{mg}$ dry biomass $\times \mathrm{h})$, while under aerobic conditions it fell to $3 \cdot 2-4 \cdot 3 \mathrm{nmol} \quad \mathrm{C}_{2} \mathrm{H}_{4} /(\mathrm{mg}$ dry biomass $\times h$ ).

The strains grew in the $\mathrm{pH}$ range $4 \cdot 5-7 \cdot 0$, the optimum being pH 5.0-5.5 (Dedysh et al., 1998b). The temperature range for growth was $10-28{ }^{\circ} \mathrm{C}$, with the optimum at approximately $20^{\circ} \mathrm{C}$; no growth occurred at $30^{\circ} \mathrm{C}$. All three strains grew well in microaerobic conditions; moreover, their specific growth rate was $10-20 \%$ higher under a reduced partial pressure of oxygen than during growth under high dissolved oxygen concentrations. The generation time was in the range $17-46 \mathrm{~h}$.

Cell growth occurred only in media with a low salt content (up to $1-1.5 \mathrm{~g}$ salt $1^{-1}$ ), the optimum salt concentration being in the range $0 \cdot 2-0 \cdot 5 \mathrm{~g}^{-1}$. Growth was completely inhibited in the presence of $\mathrm{NaCl}$ at concentrations above $0.5 \%(\mathrm{w} / \mathrm{v})$. All strains were resistant to erythromycin, linkomycin, gentamicin, novobiocin and nalidixic acid, but sensitive to streptomycin at $10 \mu \mathrm{g} \mathrm{ml}^{-1}$. Strains tolerated $0.001 \%$ crystal violet and $0.01 \%$ methylene blue, while $0.001 \%$ malachite green inhibited growth.

\section{Cellular fatty acid profiles}

The major fatty acid components of these strains of acidophilic methanotrophs were 18:1 fatty acids

Fig. 2. Electron micrographs of ultrathin sections of vegetative cells of the acidophilic methanotrophs grown under different conditions. Cells grown under normal oxygen tension showed an extensive periplasmic space on the cell periphery $(\mathrm{a}, \mathrm{b})$, inclusions of poly- $\beta$-hydroxybutyrate and polyphosphate granules formed at each cell pole (a). Spherical vesicles were formed by cytoplasmic membrane invaginations on the cytoplasm periphery (c). (d) Exospore found in 1year-old culture. Cells grown under oxygen-limiting conditions showed inclusions of supra-molecular organization: (e) longitudinal section; (f) cross-section. Bars, $0.5 \mu \mathrm{m}$. 
Table 2. Activities of enzymes of primary and intermediate metabolism in cell extracts of acidophilic methanotrophs [nmol $\mathrm{min}^{-1}\left(\mathrm{mg}\right.$ protein) $\left.{ }^{-1}\right]$

PMS, Phenyl methyl sulfonate.

\begin{tabular}{|c|c|c|c|}
\hline \multirow[t]{2}{*}{ Enzyme } & \multicolumn{3}{|c|}{ Strain } \\
\hline & S6 & $\mathbf{K}^{\mathbf{T}}$ & M131 \\
\hline Methane monooxygenase (soluble) & 73 & 83 & 53 \\
\hline Methanol dehydrogenase (PMS) & 21 & 15 & 35 \\
\hline \multicolumn{4}{|l|}{ Formaldehyde dehydrogenase } \\
\hline PMS & 3 & 2 & 2 \\
\hline $\mathrm{SH}, \mathrm{NAD}$ & 0 & 0 & 0 \\
\hline \multicolumn{4}{|l|}{ Formate dehydrogenase } \\
\hline PMS & 133 & 311 & 235 \\
\hline NAD & 112 & 232 & 207 \\
\hline NADH-dehydrogenase & 207 & 230 & 137 \\
\hline Ribulose-1,5-bisphosphate carboxylase & 0 & 0 & 0 \\
\hline Hexulosephosphate synthase & 0 & 0 & 0 \\
\hline \multicolumn{4}{|l|}{ 6-Phosphofructokinase } \\
\hline ATP & 0 & 0 & 0 \\
\hline $\mathrm{PPi}$ & 37 & 88 & 110 \\
\hline Fructose-1,6-bisphosphate aldolase & 80 & 186 & 243 \\
\hline \multicolumn{4}{|l|}{ Glucose-6-phosphate dehydrogenase } \\
\hline NAD & 25 & 30 & 7 \\
\hline NADP & 8 & 18 & 6 \\
\hline \multicolumn{4}{|l|}{ 6-Phosphogluconate dehydrogenase } \\
\hline NAD & 20 & 10 & 9 \\
\hline NADP & 0 & 0 & 0 \\
\hline KDPG aldolase & 0 & 0 & 0 \\
\hline \multicolumn{4}{|l|}{ Hydroxypyruvate reductase } \\
\hline NADH & 160 & 92 & 148 \\
\hline NADPH & 187 & 122 & 207 \\
\hline Serine-glyoxylate aminotransferase & 161 & 126 & 136 \\
\hline Pyruvate kinase & 20 & 76 & 10 \\
\hline Pyruvate dehydrogenase (NAD) & 0 & 0 & 0 \\
\hline \multicolumn{4}{|l|}{ Isocitrate dehydrogenase } \\
\hline NAD & 0 & 0 & 0 \\
\hline NADP & 10 & 10 & 104 \\
\hline$\alpha$-Ketoglutarate dehydrogenase (NAD) & 15 & 33 & 12 \\
\hline Malate dehydrogenase (NADPH) & 130 & 974 & 311 \\
\hline \multicolumn{4}{|l|}{ Glutamate dehydrogenase } \\
\hline NADH & 27 & 13 & 12 \\
\hline NADPH & 0 & 0 & 0 \\
\hline Glutamate synthase (NADH) & 10 & 19 & 8 \\
\hline Glutamine synthetase $\mathrm{Mn}^{2+}$, ATP & 23 & 24 & 7 \\
\hline
\end{tabular}

(Table 1). This is a characteristic feature of all known type II methylotrophic bacteria (Bowman et al., 1991; Guckert et al., 1991). Nevertheless, the fatty acid patterns of our isolates did not match the fatty acid patterns either of the serine-pathway methanotrophs or of the serine-pathway methylotrophic bacteria unable to use methane as a growth substrate. The most distinctive feature of the FAME patterns of strains $\mathrm{K}^{\mathrm{T}}$, S6 and M131 was the relatively large amount of 16:1 and 16:0 fatty acids (Table 1). Overall, the content of 16-carbon fatty acids in these peat-bog isolates was
$21-27 \mathrm{~mol} \%$, whereas this value never exceeded $15 \mathrm{~mol} \%$ for any of the known type II methylotrophs.

The fatty acid profile of Beijerinckia indica subsp. indica was more similar to those of members of the genus Methylobacterium than to the FAME profile of these acidophilic methanotrophs. The major fatty acids were also 18:1, but the total amount of acids with 16-carbon atoms was only $6 \mathrm{~mol} \%$. Finally, a number of minor fatty acids $(12: 0,13: 0$ and 17:0) were present in Beijerinckia indica subsp. indica, 


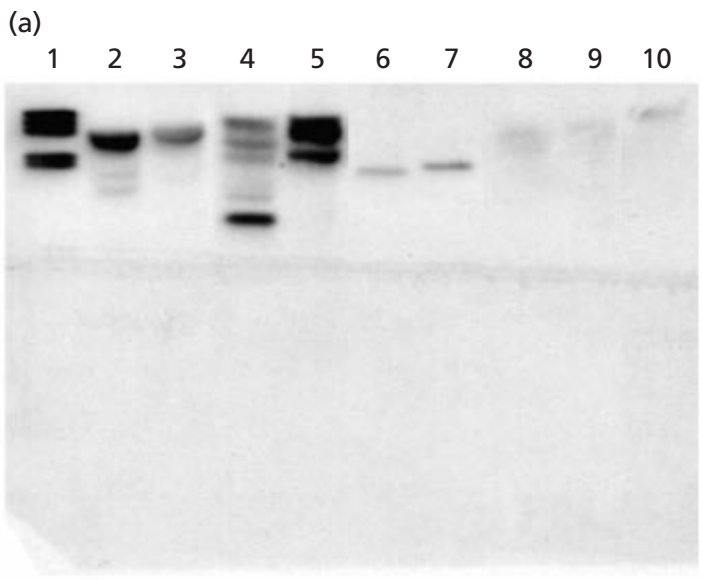

(b)

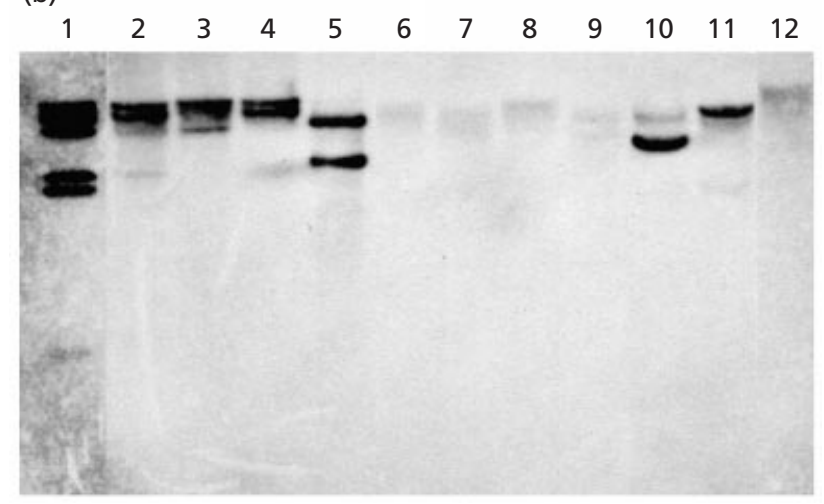

Fig. 3. Hybridization of the $p m o A$ fragment to the chromosomal DNAs of reference methane-oxidizing bacteria strains and an acidophilic methanotroph. DNAs were digested with Sall, Pstl, BamHI, EcoRI and HindIII and hybridized to the $510 \mathrm{bp}$ PCR product of the pmoA gene of Methylococcus capsulatus (Bath) labelled with digoxigenin (DIG)-dUTP. The membrane was washed at $60^{\circ} \mathrm{C}$ (a). Lanes: 1, DIG-labelled molecular mass standards; 2, Methylomicrobium album BG8 Sall digest; 3, Methylomicrobium album BG8 Pstl digest; 4, Methylococcus capsulatus (Bath) Sall digest; 5, Methylococcus capsulatus (Bath) Pstl digest; 6, Methylosinus trichosporium OB3b Sall digest; 7, Methylosinus trichosporium OB3b Pstl digest; 8, strain $\mathrm{K}^{\top}$ Sall digest; 9, strain $\mathrm{K}^{\top}$ Pstl digest; 10, Pseudomonas putida Pstl digest. The membrane was washed at $62{ }^{\circ} \mathrm{C}$ (b). Lanes: 1, DIG-labelled molecular mass standards; 2, Methylococcus capsulatus (Bath) BamHI digest; 3, Methylococcus capsulatus (Bath) EcoRI digest; 4, Methylococcus capsulatus (Bath) HindIII digest; 5, Methylococcus capsulatus (Bath) Pstl digest; 6, strain $\mathrm{K}^{\top}$ BamHI digest; 7, strain $\mathrm{K}^{\top}$ EcoRI digest; 8, strain $\mathrm{K}^{\top}$ Hindlll digest; 9, strain $\mathrm{K}^{\top}$ Pstl digest; 10, Methylomicrobium album BG8 HindIII digest; 11, Methylomicrobium album BG8 Pstl digest; 12, P. putida Pstl digest (10 $\mu \mathrm{g}$ DNA per lane).

whereas the acidophilic methanotrophs lacked all such fatty acids.

\section{Enzymological analysis}

The enzymic profiles given in Table 2 show that all three acidophilic isolates oxidize $\mathrm{CH}_{4}$ to $\mathrm{CO}_{2}$ by sequential action of sMMO and the appropriate dehydrogenases of methanol, formaldehyde and for- mate. The isolates possessed the activities of the serinepathway-specific enzymes (hydroxypyruvate reductase and serine-glyoxylate aminotransferase), whereas the activities of the key enzymes of the ribulose monophosphate pathway (hexulose phosphate synthase) or the Calvin-Benson-cycle enzymes (ribulose bisphosphate carboxylase/oxygenase and phosphoribulokinase) were not detectable. The presence of the $\alpha$-ketoglutarate dehydrogenase activity indicates that a complete tricarboxylic acid cycle exists in these methanotrophs. The acidophilic methanotrophs also have a relatively high activity of pyrophosphatedependent 6-phosphofructokinase (PPi-PFK), which is common to all methanotrophic strains tested. The presence of glutamine synthetase and glutamate synthase indicated that the isolates utilize the glutamate cycle for ammonia assimilation.

\section{PCR amplification of pmo genes and hybridization}

Using the two primer sets described in the Methods, the expected PCR products were observed from Methylococcus capsulatus (Bath), Methylosinus trichosporium $\mathrm{OB} 3 \mathrm{~b}$ and Methylomicrobium album BG8 (data are not shown). These strains were chosen as they represent the major phylogenetic categories of methanotrophs. No PCR products were obtained with template DNA extracted from strains $\mathrm{K}^{\mathrm{T}}, \mathrm{M} 131$ and S6, regardless of the primer set used. Such a finding suggests either that the pmo $A$ gene does not exist in acidophilic strains or that it is sufficiently divergent to render the primers unsuitable for amplification of this gene in acidophilic methanotrophs.

To determine if the gene encoding the $27 \mathrm{kDa}$ polypeptide of the pMMO was either present or absent from this acidophilic methanotroph, the $510 \mathrm{bp}$ PCR product encoding part of the pmo $A$ gene was hybridized to the chromosomal DNA of Methylococcus capsulatus (Bath), Methylosinus trichosporium OB3b, Methylomicrobium album BG8 and strain $\mathrm{K}^{\mathrm{T}}$. Clear hybridization of the pmo $A$ fragment was seen for the well-characterized methanotrophs, but only weak hybridization was found with the digests of strain $\mathrm{K}^{\mathrm{T}}$ chromosomal DNA on the membrane washed at low stringency $\left(60^{\circ} \mathrm{C}\right)$ (Fig. 3). A weak hybridization of the same strength was observed with the digests of Pseudomonas putida DNA used as a negative control. Upon more stringent washing, the hybridization of the pmo $A$ probe to strain $\mathrm{K}^{\mathrm{T}}$ DNA was not seen. Such weak binding may indicate either non-specific hybridization or that this gene, if present, is very divergent from that of Methylococcus capsulatus (Bath).

\section{Comparative 16S rDNA sequence analysis}

Irrespective of the $\alpha$-proteobacterial reference sequences, the set of alignment positions and the treeing method used for tree construction, strains $\mathrm{K}^{\mathrm{T}}$, M131 and S6 always grouped with the heterotrophic species Beijerinckia indica subsp. indica as the most 


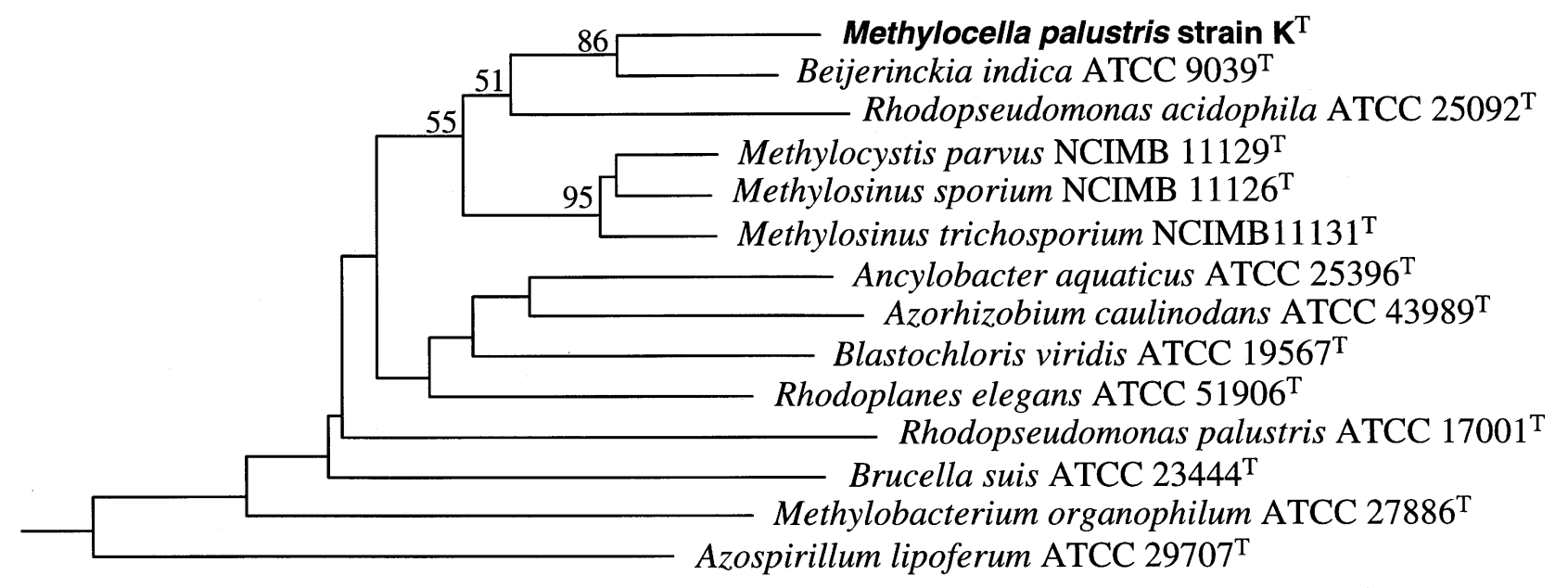

$5 \%$

Fig. 4. $16 \mathrm{~S}$ rDNA sequence-based dendrogram showing the phylogenetic position of strain $\mathrm{K}^{\top}$ in relation to representative members of the $\alpha$-subclass of the Proteobacteria. Evolutionary distances were calculated by the method of Jukes \& Cantor (1969). The dendrogram was reconstructed using the treeing algorithm of De Soete (1983). The root was determined by using the 16S rDNA sequence of Methylococcus capsulatus ATCC 19069 (accession no. X72770) as the outgroup reference. The numbers indicate the significance values for interior nodes as derived from a bootstrap test (1000 data resamplings). Bar, $5 \%$ estimated difference in nucleotide sequences.

closely related organism and were clearly distinct from the type II methanotrophs of the MethylocystisMethylosinus group (Fig. 4). The level of 16S rDNA similarity between the acidophilic methanotrophs and Beijerinckia indica was $96.5 \%$. Because our earlier detailed analysis of the 16S rDNA sequence data currently available for type II methanotrophs in public databases indicated a large amount of ambiguous nucleotide sequence positions, we sequenced the almost full-length 16S rRNA gene for the type strains of the type species of the genera Methylocystis and Methylosinus, i.e. Methylocystis parvus OBBP and Methylosinus trichosporium $\mathrm{OB} 3 \mathrm{~b}$, as well as for the type strain of Methylosinus sporium (NCIMB $11126^{\mathrm{T}}$ ). The three strains formed a tight cluster, having $16 \mathrm{~S}$ rDNA sequence similarity values between 97.5 and $98.0 \%$. The level of $16 \mathrm{~S}$ rDNA similarities between the three representatives of the MethylocystisMethylosinus group and the novel acidophilic methanotrophs ranged from $93 \cdot 3$ to $93.8 \%$.

\section{DISCUSSION}

The combination of phenotypic traits, metabolic pathways and cellular fatty acid composition, together with the results of comparative sequence analysis of 16S rRNA genes, enables the acidophilic isolates described here to be characterized as similar to (yet distinct from) the type II methanotrophs. The type II methanotrophs characterized to date comprise validated species in the genera Methylosinus and Methylocystis. Members of these two genera are very similar in their physiological, metabolic and chemo- taxonomic features, although some differences have been reported in cell morphology, the types of resting cells formed (cysts or exospores) and motility (Bowman et al., 1993; Hanson \& Hanson, 1996). On the basis of their genomic properties, all known type II methanotrophs represent a very tight group. The results of analysis of 5S rRNA (Bulygina et al., 1990) and 16S rRNA (Bratina et al., 1992) sequences indicated that these methanotrophs form a distinct and tight cluster, within the $\alpha$-subclass of the Proteobacteria, which is separate from the rest of the serinepathway methylotrophs. Subsequent investigations of the functional genes encoding key enzymes in the methane-oxidation pathway of type II methanotrophs provided further proof of this cluster homogeneity. Examination of the sMMO gene cluster of Methylocystis sp. strain M (McDonald et al., 1997) has revealed a high degree of sequence identity with the corresponding genes from Methylosinus trichosporium OB3b (Cardy et al., 1991). Comparative sequence analysis of pmo A, which encodes the $27 \mathrm{kDa}$ polypeptide of the pMMO, also placed all studied Methylosinus and Methylocystis representatives into one firm cluster (Semrau et al., 1995; Murrell \& Holmes, 1996; McDonald et al., 1997). The same conclusions were drawn from sequence analysis of the methanol dehydrogenase gene $m x a F$, encoding the large subunit of the enzyme, of a number of representative methano- and methylotrophs (McDonald \& Murrell, 1997).

Acidophilic isolates, although similar to type II methanotrophs, had significant differences that dis- 
tinguished them from representatives of both the genus Methylosinus and the genus Methylocystis. The most distinctive morphological feature of these isolates was a highly specific bipolar cell appearance not previously observed in type II methanotrophs. Furthermore, in most cases resting cells were not formed by these isolates, while some exospores were found only in several-month-old cultures. The cell ultrastructure of acidophilic methanotrophs was also radically different from those of known methanotrophs. All known MOB, regardless of type classification, develop characteristic ICM structures; the type of membrane arrangement has been used as a key taxonomic criterion since the very first classification of MOB was proposed (Whittenbury et al., 1970a; Davies \& Whittenbury, 1970). According to this criterion methanotrophs were separated into those having stacks of vesicular discs in the cytoplasmic space (type I) and those with paired membranes aligned to the periphery of the cell (type II). The ICM content is dependent on the growth conditions and is more extensive under oxygenlimiting cultivation and in media with high copper concentrations (Scott et al., 1981; Suzina et al., 1985; Phelps et al., 1992). The extent of growth is also important, with Methylosinus trichosporium OB3b shown to have a more developed ICM system during the mid-exponential, late-exponential and stationary growth phases (Best \& Higgins, 1981), while ICM degeneration has been described for Methylococcus capsulatus (Texas) as these cells age (Hyder et al., 1979). Furthermore, the ICM in type II methanotrophs has been shown to be less well ordered than that of type I methanotrophs and these cells can possess a poorly developed ICM array represented by membrane-bound vesicular structures on the cell periphery (Best \& Higgins, 1981; Scott et al., 1981; Suzina et al., 1985; Phelps et al., 1992). With these observations in mind, the acidophilic methanotrophs were examined at different stages of growth and under different culture conditions, including growth under oxygen limitation and in copper-sufficient media. To exclude subjectivity during specimen examination, the strains were investigated by specialists from three different institutions (the Center for Electron Optics at Michigan State University, the Institute of Biochemistry and Physiology of Microorganisms and the Institute of Microbiology at the Russian Academy of Sciences). Nonetheless, the peripheral membranes of the type II arrangement were not observed in any of the strains under any of the conditions tested. The characteristic feature of the cell ultrastructure was an extensive periplasmic space lacking any distinctive structures and a more-or-less developed vesicular membrane system connected to the cytoplasmic membrane and located on the cytoplasm periphery. A similar vesicular membrane system connected to the cytoplasmic membrane was described for some strains of hyphomicrobia (Conti \& Hirsch, 1965) and for the phototrophic bacteria of the genera Rhodospirillum and Rhodopseudomonas (Oelze \& Drews, 1971). The questions regarding the specifics of ICM in acidophilic methanotrophs remain to be investigated, along with the nature and function of the inclusions revealed in cells grown under oxygen limitation. The latter resemble the toxin inclusions found in some Bacillus thuringiensis cells (Cooksey, 1971) and peroxisomal structures in methylotrophic yeasts (Sulter et al., 1993). In view of all the above data, the cell ultrastructure of acidophilic methanotrophs appears to differ from those of other MOB and the type of ICM arrangement should be considered to be new and distinct.

The physiology of bog methanotrophs is quite consistent with the conditions of their natural habitat. The Sphagnum peat bogs are representative of an acidic and extra-dilute environment with a salt content of approximately 5-50 $\mathrm{mg}$ (1 peat water $)^{-1}$. Our isolates exhibited a high level of sensitivity to salt stress and grew better in media with a low salt content $(0 \cdot 2-0 \cdot 5 \mathrm{~g}$ $1^{-1}$ ). The conventional mineral media (with a salt content of approx. 1·5-3 $\mathrm{g} \mathrm{l}^{-1}$ ) would not support the growth of these isolates. This criterion clearly distinguishes bog isolates from the known MOB and places them at the opposite end of the spectrum from the recently discovered alkaliphilic methanotrophs (which prefer high salt concentrations; Khmelenina et al., 1997). The acidophilic nature of bog isolates is another characteristic that makes them different from known MOB. While these bacteria can be grown over a wide range of $\mathrm{pH}$ values (including semi-neutral media), optimal growth occurs at $\mathrm{pH}$ values between $5 \cdot 0$ and $5 \cdot 5$, which is typical of moderately acidophilic organisms.

Analysis of the metabolic pathways in these cells has shown that the acidophilic isolates use the serine pathway for carbon assimilation and the glutamate cycle for $\mathrm{NH}_{4}^{+}$assimilation in much the same way as all known type II methanotrophs. The bog isolates contain PPi-PFK, a highly specific MOB characteristic, but uncommon in methylotrophic bacteria. Some peculiarities of central metabolism, however, were found in the acidophilic methanotrophs. Both NADHand NADPH-specific hydroxypyruvate reductase activities were detected whereas the NADH-specific enzyme is more common in type II methanotrophs. Also, the acidophilic isolates were found to possess enzymes for the pentose phosphate pathway (i.e. glucose-6-phosphate dehydrogenase and 6-phosphogluconate dehydrogenase) at levels almost equal to those found in type I methanotrophs. These enzymes have not been previously detected in MOB with the serine pathway for carbon assimilation. The presence of pyruvate kinase activity is another distinctive metabolic feature as this enzyme has not been found in any known obligate MOB. Our recent study shows that the pattern of carbohydrate metabolism in these acidophilic methanotrophs shows some similarity to that of Beijerinckia indica subsp. indica (V. N. Khmelenina \& Y. A. Trotsenko, unpublished results), further supporting the conclusion that these bacteria are closely related. 
Table 3. Major characteristics that distinguish Methylocella gen. nov. and other genera of type II methanotrophs

\begin{tabular}{|c|c|c|c|}
\hline Characteristic & Methylosinus & Methylocystis & Methylocella \\
\hline Cell morphology & Vibrioid or pyriform & $\begin{array}{l}\text { Coccobacillary or } \\
\text { curved rods }\end{array}$ & $\begin{array}{l}\text { Bipolar straight or } \\
\text { curved rods }\end{array}$ \\
\hline Motility & $+1-$ & - & - \\
\hline Rosette formation & + & - & - \\
\hline Type of resting cells & Exospores & Cysts & Exospores \\
\hline $\begin{array}{l}\text { Arrangement of } \\
\text { intracytoplasmic } \\
\text { membrane structure }\end{array}$ & $\begin{array}{l}\text { Paired membranes } \\
\text { aligned to periphery } \\
\text { of cell (type II) }\end{array}$ & $\begin{array}{l}\text { Paired membranes } \\
\text { aligned to periphery } \\
\text { of cell (type II) }\end{array}$ & $\begin{array}{l}\text { Vesicular membrane } \\
\text { system connected to } \\
\text { the cytoplasmic } \\
\text { membrane }\end{array}$ \\
\hline Growth at $30^{\circ} \mathrm{C}$ & + & + & - \\
\hline Growth at $\mathrm{pH} 5 \cdot 0$ & - & - & + \\
\hline $\begin{array}{l}\text { Growth at } 0.05 \% \\
\mathrm{NaCl}\end{array}$ & + & + & - \\
\hline Possess sMMO & $+1-$ & $+/-$ & + \\
\hline Possess pMMO & + & + & - \\
\hline $\begin{array}{l}\text { Possess pyruvate } \\
\text { kinase }\end{array}$ & - & - & + \\
\hline $\begin{array}{l}\mathrm{G}+\mathrm{C} \text { composition } \\
(\mathrm{mol} \%)\end{array}$ & $62-67$ & $62-67$ & 61 \\
\hline $\begin{array}{l}\text { Closest phylogenetic } \\
\text { relative }\end{array}$ & Methylocystis & Methylosinus & Beijerinckia \\
\hline
\end{tabular}

The fatty acid pattern of the acidophilic methanotrophs had a predominance of 18:1 acids, similar to that found in all type II methylotrophic bacteria (Bowman et al., 1991; Guckert et al., 1991). Despite such a basic similarity, the complete fatty acid profile did not match the fatty acid patterns either of the serine-pathway methanotrophs or of the serine-pathway methylotrophic bacteria unable to use methane. Interestingly, perhaps the most distinctive feature of the FAME patterns of the bog isolates was the relatively large amount of both 16:1 and 16:0 fatty acids (see the corresponding section in Results).

The updated 16S rDNA sequence data of the type strains of Methylosinus sporium, Methylosinus trichosporium and Methylocystis parvus clearly indicate that the Methylosinus-Methyocystis cluster is an even less phylogenetically diverse group than was previously thought. This finding provides further evidence of the evolutionary distinction between the acidophilic methanotrophs and the Methylosinus-Methyocystis cluster. The mmoX gene sequence data strongly support the above conclusion. As reported earlier, the mmo $X$ gene sequence in acidophilic methanotrophs is significantly divergent from that in other methanotrophs (Dedysh et al., 1998b). The DNA sequences of the gene cluster encoding the sMMO proteins of Methylococcus capsulatus (Bath), Methylosinus trichosporium $\mathrm{OB} 3 \mathrm{~b}$ and Methylocystis sp. strain M (Stainthorpe et al., 1990;Cardy et al., 1991; McDonald et al., 1997) are highly conserved. For the mmoX gene fragment investigated in our study, the amino acid sequences of Methylosinus trichosporium OB3b and Methylocystis sp. strain M had $93.7 \%$ identity, whereas the levels of identity with the same fragment of Methylococcus capsulatus (Bath) are 73.0 and $77.4 \%$, respectively. The $m m o X$ gene fragment of acidophilic isolates showed an equal level of divergence from the Methylosinus-Methylocystis group and from Methylococcus capsulatus (Bath). The levels of sequence divergence $(76.5-78.6$ and $78.0 \%$, respectively) indicated that the mmoX gene of the acidophilic isolates forms a separate branch clearly distinct from the $m m o X$ sequences of the Methylocystis-Methylosinus and Methylococcus groups.

PCR amplification of pmoA gene fragments from DNA of all three acidophilic strains was unsuccessful using two sets of primers, although both sets were clearly useful for amplifying the corresponding fragment from type I, II and X methanotrophs. These results were confirmed by specialists of three different institutions (the Center for Microbial Ecology at Michigan State University, the Max-Planck-Institut für Terrestrische Mikrobiologie in Marburg and the Department of Civil and Environmental Engineering at the University of Michigan). Furthermore, the hybridization of the $510 \mathrm{bp}$ pmo $A$ probe was only slightly visible with low-stringency washing, suggesting that the DNA fragment to which this probe is bound in strain $\mathrm{K}^{\mathrm{T}}$ has only slight similarity to that of the probe generated from Methylococcus capsulatus (Bath). These results are very intriguing and suggest that the 
gene encoding the $27 \mathrm{kDa}$ polypeptide, if present in strain $\mathrm{K}^{\mathrm{T}}$, is very divergent from that of other methanotrophs. As these acidophilic isolates are relatively dissimilar to other known methanotrophs phenotypically, metabolically and on the basis of $16 \mathrm{~S} \mathrm{rDNA}$ and $m m o X$ sequence data, the possibility that the cells do not have the capacity to express the pMMO should be considered and investigated further with other probes based on other genes in the pmo operon.

On the basis of these results, it is our conclusion that these isolates be placed in a separate taxon, for which we propose the generic name Methylocella, with the type species Methylocella palustris. The major characteristics differentiating the genus Methylocella from the other genera of the serine pathway methanotrophs are summarized in Table 3.

\section{Description of Methylocella gen. nov.}

Methylocella (Me.thyl.o.cel'la. M.L. n. methyl the methyl group; L. n. cella a cell; M.L. n. Methylocella methyl-using cell).

Gram-negative, polymorphic, straight or curved short rods that are $0.6-1 \cdot 0 \mu \mathrm{m}$ wide by $1.0-2.5 \mu \mathrm{m}$ long with rounded ends. Produce large, highly refractile, intracellular poly- $\beta$-hydroxybutyrate granules (one at each pole). Reproduce by normal cell division. Cells occur singly or in shapeless aggregates, but do not form rosettes. Non-motile. Encapsulated. Resting cells are exospores. Cells are not lysed by $2 \%$ SDS. The ICM system is different from those of both type I and type II methanotrophic bacteria. Cells contain an extensive periplasmic space and a vesicular membrane system connected to the cytoplasmic membrane. Possess $\mathrm{SMMO}$. Optimal growth occurs at temperatures between 15 and $20^{\circ} \mathrm{C}$; no growth occurs at temperatures above $30^{\circ} \mathrm{C}$. Growth occurs between pH 4.5 and 7.0. Highly sensitive to salt stress; prefers diluted media with a low salt content. Obligate utilizer of $\mathrm{C}_{1}$ compounds via the serine pathway. Does not contain the RuMP and RuBP enzymes. The tricarboxylic acid cycle is complete. Fixes atmospheric nitrogen via an oxygen-sensitive nitrogenase. The major phospholipid ester-linked fatty acids are 18:1 acids. The $\mathrm{G}+\mathrm{C}$ content of the DNA is $61.2 \mathrm{~mol} \%$. Phylogenetically related to, but clearly distinct from, the coherent group of type II methanotrophs in the $\alpha$-subclass of the Proteobacteria; more closely affiliated with the acidophilic heterotrophic bacterium Beijerinckia indica subsp. indica. Contains one species, Methylocella palustris, which includes the type strain, $\mathrm{K}^{\mathrm{T}}$. Habitats are the acidic wetlands, particularly Sphagnum peat bogs.

\section{Description of Methylocella palustris sp. nov.}

Methylocella palustris (pa.lus'tris. L. n. palus a bog; M.L. adj. palustris bog-inhabiting).

The description is as for the genus but with the following additional traits. Optimal growth at $20^{\circ} \mathrm{C}$ and at $\mathrm{pH} 5 \cdot 5$. Carbon sources used include methane and methanol. $\mathrm{NaCl}$ inhibits growth at a concentration of $0.5 \%(\mathrm{w} / \mathrm{v})$. The type strain is strain $\mathrm{K}^{\mathrm{T}}$, which was isolated from Sphagnum peat from the Kyrgyznoye ombrotrophic bog in West Siberia $\left(56^{\circ} \mathrm{N}, 85^{\circ} \mathrm{E}\right)$ and is deposited in the American Type Culture Collection (Manassas, VA) as strain $700799^{\mathrm{T}}$. The species also includes strains S6 and M131.

\section{ACKNOWLEDGEMENTS}

We are grateful to Frank Dazzo (Center for Microbial Ecology at Michigan State University), Carol Flegler (Michigan State University Center for Electron Optics) and N. A. Kostrykina (Institute of Microbiology of the Russian Academy of Sciences) for phase-contrast- and electron microscopy. We also thank Sandy Marsh and Michel Cavigelli (Kellogg Biological Station at Michigan State University) for their help with whole-cell fatty acid analysis. This research was supported, in part, by the Russian Fund for Fundamental Research (grant nos 98-04-144 and 990448725), NSF grant nos INT 9315089 and DEB 9120006, an NIH Cellular Biotechnology Training Program grant (2T32GM08353-06) and a grant from the Deutsche Forschungsgemeinschaft (436 RUS 113/543/0).

\section{REFERENCES}

Becking, J.-H. (1984). Genus Beijerinckia. In Bergey's Manual of Systematic Bacteriology, vol. 1, pp. 311-321. Edited by N. R. Krieg \& J. G. Holt. Baltimore: Williams \& Wilkins.

Best, D. J. \& Higgins, I. J. (1981). Methane-oxidizing activity and membrane morphology in a methanol-grown obligate methanotroph, Methylosinus trichosporium OB3b. J Gen Microbiol 125, 73-84.

Bodrossy, L., Holmes, E. M., Holmes, A. J., Kovacs, K. L. \& Murrell, J. C. (1997). Analysis of $16 \mathrm{~S}$ rRNA and methane monooxygenase gene sequences reveals a novel group of thermotolerant and thermophilic methanotrophs, Methylocaldum gen. nov. Arch Microbiol 168, 493-503.

Bowman, J. P., Skerratt, J. H., Nichols, P. D. \& Sly, L. I. (1991). Phospholipid fatty acid and lipopolysaccharide fatty acid signature lipids in methane-utilizing bacteria. FEMS Microbiol Ecol 85, 15-22.

Bowman, J. P., Sly, L. I., Nichols, P. D. \& Hayward, A. C. (1993). Revised taxonomy of the methanotrophs: description of Methylobacter gen. nov., emendation of Methylococcus, validation of Methylosinus and Methylocystis species, and a proposal that the family Methylococcaceae includes only the group I methanotrophs. Int J Syst Bacteriol 43, 735-753.

Bowman, J.P., McCammon, S. A. \& Skerratt, J. H. (1997). Methylosphaera hansonii gen. nov., sp. nov., a psychrophilic, group I methanotroph from Antarctic marine-salinity, meromictic lakes. Microbiology 143, 1451-1459.

Bratina, B. J., Brusseau, G. A. \& Hanson, R. S. (1992). Use of $16 \mathrm{~S}$ rRNA analysis to investigate phylogeny of methylotrophic bacteria. Int J Syst Bacteriol 42, 645-648.

Bulygina, E. S., Galchenko, V. F., Govorukhina, N. I., Netrusov, A. I., Nikitin, D. I., Trotsenko, Y. A. \& Chumakov, K. M. (1990). Taxonomic studies on methylotrophic bacteria by $5 \mathrm{~S}$ ribosomal RNA sequencing. J Gen Microbiol 136, 441-446.

Cardy, D. L. N., Laidler, V., Salmond, G. P. C. \& Murrell, J. C. (1991). Molecular analysis of the methane monooxygenase 
(MMO) gene cluster of Methylosinus trichosporium OB3b. Mol Microbiol 5, 335-342.

Conti, S. F. \& Hirsch, P. (1965). Biology of budding bacteria. III. Fine structure of Rhodomicrobium and Hyphomicrobium spp. $J$ Bacteriol 89, 503-512.

Cooksey, K. E. (1971). The protein crystal toxin of Bacillus thuringiensis: biochemistry and mode of action. In Microbial Control of Insects and Mites, pp. 247-274. New York: Academic Press.

Costello, A. \& Lidstrom, M. E. (1999). Molecular characterization of functional and phylogenetic genes from natural populations in lake sediments. Appl Environ Microbiol 65, 5066-5074.

Davies, S. L. \& Whittenbury, R. (1970). Fine stucture of methane and other hydrocarbon-utilizing bacteria. J Gen Microbiol 61, 227-232.

Dedysh, S. N., Panikov, N. S. \& Tiedje, J. M. (1998a). Acidophilic methanotrophic communities from Sphagnum peat bogs. Appl Environ Microbiol 64, 922-929.

Dedysh, S. N., Panikov, N. S., Liesack, W., Großkopf, R., Zhou, J. \& Tiedje, J. M. (1998b). Isolation of acidophilic methane-oxidizing bacteria from northern peat wetlands. Science 282, 281-284.

De Soete, G. (1983). A least square algorithm for fitting additive trees to proximity data. Psychometrika 48, 621-626.

Felsenstein, J. (1993). PHYLIP (phylogeny inference package), version 3.5c. Department of Genetics, University of Washington, Seattle, WA, USA.

Friedrich, M., Springer, N., Ludwig, W. \& Schink, B. (1996). Phylogenetic positions of Desulfofustis glycolicus gen. nov., sp. nov., and Syntrophobotulus glycolicus gen. nov., sp. nov., two new strict anaerobes growing with glycolic acid. Int $J$ Syst Bacteriol 46, 1065-1069.

Gerhardt, P. (1981). Manual of Methods for General Bacteriology. Washington, DC: American Society for Microbiology.

Guckert, J. B., Ringelberg, D. B., White, D. C., Hanson, R. S. \& Bratina, B. J. (1991). Membrane fatty acids as phenotypic markers in the polyphasic taxonomy of methylotrophs within the Proteobacteria. J Gen Microbiol 137, 2631-2641.

Hanson, R. S. \& Hanson, T. E. (1996). Methanotrophic bacteria. Microbiol Rev 60, 439-471.

Holmes, A. J., Costello, A., Lidstrom, M. E. \& Murrell, J. C. (1995). Evidence that particulate methane monooxygenase and ammonia monooxygenase may be evolutionarily related. FEMS Microbiol Lett 132, 203-208.

Hyder, S. L., Meyers, A. \& Cayer, M. L. (1979). Membrane modulation in a methylotrophic bacterium Methylococcus capsulatus (Texas) as a function of growth substrate. Tissue Cell 11, 597-610.

Jukes, T. H. \& Cantor, C. R. (1969). Evolution of protein molecules. In Mammalian Protein Metabolism, pp. 21-132. Edited by H. N. Munro. New York: Academic Press.

Khmelenina, V. N., Kalyuzhnaya, M. G., Starostina, N. G., Suzina, N. E. \& Trotsenko, Y. A. (1997). Isolation and characterization of halotolerant alkaliphilic methanotrophic bacteria from Tuva soda lakes. Curr Microbiol 35, 257-261.

King, G. M. (1992). Ecological aspects of methane oxidation, a key determinant of global methane dynamics. Adv Microb Ecol 12, 431-461.

Liu, J., Yu, B., Jain, A. K., Glagoleva, O. \& Dazzo, F. B. (1998). Image Analysis System. In Progress \& Abstracts of the 8th
Symposium on Microbial Ecology, p. 218. Halifax: Center for Microbial Ecology.

McDonald, I. R. \& Murrell, J. C. (1997). The methanol dehydrogenase structural gene $m x a F$ and its use as a functional gene probe for methanotrophs and methylotrophs. Appl Environ Microbiol 63, 3218-3224.

McDonald, I. R., Kenna, E. M. \& Murrell, J. C. (1995). Detection of methanotrophic bacteria in environmental samples with PCR. Appl Environ Microbiol 61, 116-121.

McDonald, I. R., Uchiyama, H., Kambe, S., Yagi, O. \& Murrell, J. C. (1997). The soluble methane monooxygenase gene cluster of the trichloroethylene-degrading methanotroph Methylocystis sp. strain M. Appl Environ Microbiol 63, 1898-1904.

Maidak, B. L., Olsen, G. J., Larsen, N., Overbeek, R., McCaughey, M. J. \& Woese, C. R. (1997). The RDP (Ribosomal Database Project). Nucleic Acids Res 25, 109-110.

Murrell, J. C. \& Holmes, A. J. (1996). Molecular biology of particulate methane monooxygenase. In Microbial Growth on $C_{1}$ Compounds, pp. 133-140. Edited by M. E. Lidstrom \& F. R. Tabita. Dordrecht: Kluwer.

Oelze, J. \& Drews, G. (1971). Membranes of photosynthetic bacteria. Biochim Biophys Acta 265, 209-239.

Omelchenko, M., Vasilyeva, L. V. \& Zavarzin, G. A. (1993). Psychrophilic methanotroph from tundra soil. Curr Microbiol 27, 255-259.

Owen, R. J., Lapage, S. P. \& Hill, L. R. (1969). Determination of base composition from melting profiles in dilute buffers. Biopolymers 7, 503-516.

Pfennig, N. (1969). Rhodopseudomonas acidophila, sp. n., a new species of the budding purple nonsulfur bacteria. J Bacteriol 99 , 597-602.

Phelps, P. A., Agarwal, S. K., Speitel, G. E. \& Georgiou, G. (1992). Methylosinus trichosporium OB3b mutants having constitutive expression of soluble methane monooxygenase in the presence of high levels of copper. Appl Environ Microbiol 58, 3701-3708.

Reynolds, E. S. (1963). The use of lead citrate at high $\mathrm{pH}$ as an electron-opaque stain in electron microscopy. J Cell Biol 17, 208-212.

Sambrook, J., Fritsch, E. F. \& Maniatis, T. (1989). Molecular Cloning : a Laboratory Manual, 2nd edn. Cold Spring Harbor, NY : Cold Spring Harbor Laboratory.

Sasser, M. (1990). Technical Note 101 : Identification of Bacteria By Gas Chromatography of Cellular Fatty Acids. Newark: MIDI.

Scott, D., Brannan, J. \& Higgins, I. J. (1981). The effect of growth conditions on intracytoplasmic membranes and methane monooxygenase activities in Methylosinus trichosporium OB3b. J Gen Microbiol 125, 63-72.

Semrau, J. D., Chistoserdov, A., Lebron, J. \& 7 other authors (1995). Particulate methane monooxygenase genes in methanotrophs. J Bacteriol 177, 3071-3079.

Shishkina, V. N. \& Trotsenko, Y. A. (1979). Pathways of ammonia assimilation in obligate methane-utilizers. FEMS Microbiol Lett 5, 187-191.

Shishkina, V. N. \& Trotsenko, Y. A. (1982). Multiple metabolic lesions in obligate methanotrophic bacteria. FEMS Microbiol Lett 13, 237-242.

Stainthorpe, A. C., Lees, V., Salmond, G. P. C., Dalton, H. \& Murrell, J. C. (1990). The methane monooxygenase cluster of Methylococcus capsulatus (Bath). Gene 91, 27-34. 
Strunk, O., Gross, O., Reichel, B. \& 11 other authors (1996). ARB: a software environment for sequence data. Available on-line at http://www.biol.chemie.tu-muenchen.de/pub/ARB/.

Munich: Technische Universität München.

Sulter, G., Veenhuis, M. \& Harder, W. (1993). A molecular analysis of peroxisome biogenesis and function in the methylotrophic yeast Hansenula polymorpha. In Microbial Growth on C1 compounds, pp. 193-207. Edited by J. C. Murrell \& D. P. Kelly. Andover: Intercept.

Suzina, N. E., Chetina, E. V., Trotsenko, Yu, A. \& Fikhte, B. A. (1985). Influence of culturing conditions on organization of membrane apparatus and surface tubular structures of Methylocystis echinoides cells. Microbiology (English translation of Mikrobiologiya) 54, 169-176.

Takeda, K. (1988). Characteristics of a nitrogen-fixing methanotroph, Methylocystis T-1. Antonie Leeuwenhoek 54, 521-534.

Weisburg, W. G., Barns, S. M., Pelletier, D. A. \& Lane, D. J. (1991). $16 \mathrm{~S}$ ribosomal DNA amplification for phylogenetic study. $J$ Bacteriol 173, 697-703.

Whittenbury, R., Phillips, K. C. \& Wilkinson, T. F. (1970a). Enrichment, isolation and some properties of methane-utilizing bacteria. J Gen Microbiol 61, 205-218.

Whittenbury, R., Davies, S. L. \& Davey, J. F. (1970b). Exospores and cysts formed by methane-utilizing bacteria. J Gen Microbiol 61, 219-226.

Zhou, J., Davey, M. E., Figueras, J. B., Rivkina, E., Gilichinsky, D. \& Tiedje, J. M. (1997). Phylogenetic diversity of a bacterial community determined from Siberian tundra soil DNA. Microbiology 143, 3913-3919. 